\title{
Jak to robią w Nowym Jorku? Polonisty obrazki z podróży do Ameryki
}

\section{How do they do it in New York? The Polish Philologist images from a journey to America}

\author{
|Witold Bobiński
}

\begin{abstract}
The article concerns the authors visit to Columbia University Teachers College in New York. TC is known to be one of the most prestigious centres of teachers' education in the United States. It is the place where the modern didactic discourse on mother tongue education has been highly developed in the last decades. The specificity of TC's educational program lies in the importance of philosophical issues and courses in the art of teaching. The two-semester long professional practices in NY schools are the core of the teacher's education process in TC. In addition to the information about the content of English Teaching programs in TC, the article also contains a comment on some of the academic teaching methods used in Teachers College, especially those connected with the use of multimedia. Another aspect of the article is the report on several English and Humanities lessons visited in NY schools, where the author had an opportunity to see some techniques leading to the authentic, visible learning.
\end{abstract}

Key words: Teachers College, teachers' education, university didactics, mother tongue education;

Streszczenie: Artykuł jest relacją z pobytu studyjnego w Columbia University Teachers College w Nowym Jorku. Uczelnia ta jest jedną z najbardziej prestiżowych w USA placówek kształcących nauczycieli. Nowy Jork natomiast to ważny ośrodek współczesnej amerykańskiej myśli dydaktycznej, także w dziedzinie nauczania w języku ojczystym. Autor omawia specyfikę studiów nauczycielskich w TC, podkreślając zwłaszcza rolę obszernego komponentu treści filozoficznych i ogólnopedagogicznych oraz dwusemestralnego, mocno angażującego studentów stażu nauczycielskiego. Informacji o merytorycznej zawartości przedmiotów i kursów, prowadzących do uzyskania uprawnień nauczyciela języka angielskiego, towarzyszy refleksja na temat modelu dydaktyki akademickiej realizowanego w TC, w tym zwłaszcza na temat wykorzystania multimediów w procesie kształcenia. Równoległym wątkiem rozważań są relacje z lekcji przedmiotów humanistycznych, głównie ELA (English Language Arts, odpowiednik języka polskiego), odznaczających się przede wszystkim wykorzystaniem różnych technik wywoływania zjawiska autentycznego uczenia się młodych ludzi.

Słowa kluczowe: Teachers College, kształcenie nauczycieli, kształcenie akademickie, edukacja w języku ojczystym. 
Edukacja amerykańska nie ma szczególnie dobrej marki. Nie ma w potocznej opinii - bo już we współczesnym dyskursie edukacyjnym pozycje autorów amerykańskich uważane są za ważne i mocno wsparte na fundamencie badań empirycznych. W potocznej opinii jest jednak trochę racji. Mówienie o amerykańskiej oświacie w ogóle czy amerykańskiej szkole jest bowiem skazane na daleko idące uogólnienia, które - zapewne pod wpływem filmu - kształtowane są przez obrazy południa i zachodu Stanów Zjednoczonych, gdzie diabeł mówi dobranoc. Od ludzi „bywałych”, a także niektórych ekspertów od edukacji wielokrotnie słyszałem o fatalnym poziomie wykształcenia młodych Amerykanów, których wiedza o świecie współczesnym i dawnym ogranicza się do kompromitujących banałów, powtarzanych przez całe życie. Muszę, gwoli prawdy, przyznać, że jest to opinia z troską podzielana przez wielu Amerykanów.

A jednak, po krótkim pobycie w Nowym Jorku, po dłuższym (i wciąż odnawianym) romansie $\mathrm{z}$ amerykańską literaturą edukacyjną, po rozmowach, warsztatach, zajęciach z udziałem wykładowców i nauczycieli - jestem pod ogromnym wrażeniem amerykańskiego (precyzyjnie mówiąc: nowojorskiego) dążenia do organizacji szkoły, która stara się odpowiadać na najważniejsze potrzeby i wyzwania współczesności, szkoły przyjaznej uczniom i skutecznej, nowoczesnej, a jednocześnie zakorzenionej w „odwiecznym”, amerykańskim etosie pracowitości i poświęcenia na rzecz wspólnoty. Moje wrażenia i obserwacje dotyczą, rzecz jasna, wycinka amerykańskiej rzeczywistości szkolnej, jest to jednak wycinek - w moim mniemaniu - najistotniejszy, centralny i kluczowy dla stanu i rozwoju edukacji w USA - wycinek nowojorski.

Niewyszukana metafora z poprzedniego akapitu niech mi będzie wybaczona przez skojarzenie geograficzno-wizualne - na mapie USA Nowy Jork stanowi wszak coś na kształt „wycinka” - „wycina się” bowiem z korpusu kontynentu wyspą Manhattan i kilkoma innymi, wchodzącymi w skład miasta (Coney Island, Staten Island, Long Island). Metafora jest niedoskonała, ale o tyle uprawniona, iż nowoczesna amerykańska teoria i praktyka edukacyjna rodzi się w istocie na małym wycinku lądu - na wyspie Manhattan i stąd promieniuje na zewnątrz - z Teachers College (Columbia University), z New York University. Moje doświadczenia związane są z pobytem w pierwszej z tych uczelni. Na zakończenie wstępu muszę zaznaczyć, iż tekst mój jest - poszerzoną o pobieżny rekonesans poznawczy - relacją z podróży, niech mi więc będzie wybaczona powierzchowność i emocjonalność poniższych zapisków ${ }^{1}$.

\section{Być belfrem po Teachers College...}

to oznacza, w pierwszym rzędzie, zostać przyjętym w poczet studentów tej, afiliowanej przy Columbia University, samodzielnej uczelni kształcącej nauczycieli. Kto zatem na odpowiednio wysokim poziomie poradzi

${ }^{1}$ Podróż do Nowego Jorku zawdzięczam hojności fundatora warszawskiej Szkoły Edukacji, powołanej przez Polsko-Amerykańską Fundację Wolności, w kooperacji z Uniwersytetem Warszawskim. 
sobie z egzaminami otwierającymi drogę na studia magisterskie (Graduate Record Examination lub Millers Analogies Test), uzyska stopień licencjata (baccalaureate), wypełni obszerną, 7-stopniową aplikację, zgromadzi potrzebne dokumenty i przygotuje sumę co najmniej 9000 dolarów za każdy semestr nauki (mechanizm obliczeniowy jest prosty - około 1,5 dolara za 1 punkt ECTS) - ten może wstępować w progi szacownej szkoły wyższej, założonej w 1887 roku (sama Columbia jest na warunki amerykańskie niemal prehistoryczną uczelnią, jako Kings College powołali ją jeszcze Brytyjczycy w 1754 roku). Trzysemestralne studia (II stopnia) dające prawo nauczania języka angielskiego (co ciekawe: zasadniczo w stanie Nowy Jork i samym mieście ${ }^{2}$ ) rozpoczynają więc absolwenci z tytułem licencjata (niekoniecznie z dziedziny kierunkowej), a istotnym czynnikiem przy rekrutacji są wyniki kandydata uzyskane z przedmiotu Language Arts (po naszemu: język angielski) w klasach od 7 do 12, czyli w wieku 13 - 18 lat. Świadectwa za ten okres nauki należą właśnie do zestawu owych „potrzebnych dokumentów", składanych w trakcie aplikacji.

Dziedziny do studiowania są w Teachers College (TC) rozlokowane pomiędzy tzw. „obszary studiów” (bardziej zgodnie z duchem polszczyzny brzmiałyby pewnie „obszary nauk” czy „obszary wiedzy”). Bratnia w stosunku do filologii polskiej dziedzina nosi nazwę Teaching of English \& English Education i mieści się w obszarze Teacher Education \& Teacher Certification, co oznacza, że ukończenie studiów na tym wydziale uprawnia absolwentów do podjęcia pracy w szkole w charakterze nauczycieli.

Czego właściwie uczą się przyszli szkolni angliści (nauczyciele przedmiotu Language Arts, czemu najbliżej do „umiejętności językowych”) w trakcie studiów w Teachers College? Mają do wyboru dwa programy magisterskie (Master of Arts i Master of Education, ten pierwszy bliższy jest naszym standardowym studiom nauczycielskim) oraz trzy doktorskie (Doctor of Education, Doctor of Education in College Teaching, Doctor of Philosophy). Wszystkie programy prowadzące do doktoratu są w różnym stopniu nasycone treściami, które najlepiej określić jako filozofię edukacji, ostatni z wymienionych, oczywiście, w stopniu najwyższym). Ażeby zostać nauczycielem języka angielskiego w stanie Nowy Jork, trzeba najpierw uzyskać certyfikat zwany „początkowym” (Initial Certificate), który daje prawo nauczania przez 5 lat i rutynowo prowadzi do - powiedzielibyśmy - awansu zawodowego i uzyskania bezterminowo ważnego Proffesional Certificate, czyli - z grubsza rzecz biorąc - naszego stopnia nauczyciela mianowanego. Przyjrzyjmy się zatem programowi studiów, które dają młodemu człowiekowi kwalifikacje do nauczania przedmiotu Language Arts. Oto lista przedmiotów i kursów, które obowiązani są zrealizować studenci specjalności Master of Arts na kierunku English Education (podaję w angielskim brzmieniu, dodając tłumaczenie i gdzieniegdzie dodatkowe informacje):

${ }^{2}$ Stosunkowo łatwo uzyskać certyfikat uprawniający do nauczania także w innych stanach. 
- English methods (Metody nauczania języka angielskiego)

- Teaching of Reading (Nauczanie czytania, rozumiane także jako kształcenie umiejętności analizy i interpretacji)

- Teaching of Writing (Nauczanie pisania, kurs ten, wraz z wymienionym powyżej, zawiera komponent treści dotyczący kształcenia językowego, któremu jednak daleko do znanej nam „gramatyki”).

- Teaching English in diverse social and cultural contexts (Nauczanie angielskiego w różnych kontekstach społecznych i kulturowych).

- Dodatkowo studenci muszą wybrać jeden spośród niżej podanych kursów:

- Literature and teaching (Literatura i nauczanie)

- Literacies and technologies in the secondary English classroom (Kompetencje komunikacyjne a technologie w nauczaniu angielskiego w szkole ponadpodstawowej $\left.{ }^{3}\right)$

- Teaching of poetry (Uczenie o poezji ${ }^{4}$ )

Program studiów prowadzących do tytułu Master of Arts obejmuje także tzw. wymagania przedmiotowe (Content requirement). Dzielą się one na segmenty Writing i Literature, z których trzeba wybrać po jednym kursie (jeśli jeden został już wybrany w ramach przedmiotów dodatkowych, trzeba wybrać drugi).

\section{Writing:}

- Writing: Nonfiction (Nauka pisania tekstów typu nonfiction)

- Teaching narrative and story (Nauka pisania tekstów narracyjnych)

\section{Literature:}

- Literature and teaching

- Cultural perspectives and literature (Perspektywy kulturowe a edukacja literacka)

Oprócz wymienionych wyżej kursów studenci przygotowujący się do zawodu nauczyciela przedmiotu Language Arts w stanie Nowy Jork i w samym mieście są obowiązani do zdobycia wiedzy z dziedzin takich, jak historia i filozofia edukacji, psychologiczne aspekty procesu nauczania/ uczenia się (w tym także kwestie dysfunkcji, deficytów, specjalnych potrzeb edukacyjnych) oraz - używając swobodnego tłumaczenia - ponadprzedmiotowa, ogólnodydaktyczna sztuka nauczania. Komponent treści kształcenia

\footnotetext{
${ }^{3}$ Pojęcie literacy jest trudno (można by rzec: coraz trudniej) przetłumaczalne, w miarę jak jego zakres znaczeniowy ulega poszerzeniu. Początkowo oznaczało piśmienność i umiejętność czytania (biegłość w obu tych dziedzinach), współcześnie obejmuje także sprawności takie jak oglądanie, słuchanie, mówienie i projektowanie (działań) w stopniu umożliwiającym efektywne komunikowanie się z otoczeniem czy, po prostu, satysfakcjonujące życie w społeczeństwie. Wymienione w nazwie kursu „technologie” odnoszą się do cyfrowych narzędzi i sposobów komunikacji i wszelkiej aktywności kulturowej.

${ }^{4}$ „Uczenie o poezji” wydaje się bardziej adekwatne wobec istoty tego kursy niż np. „Nauczanie poezji". To drugie bowiem może sugerować, iż chodzi tu także o coś w rodzaju warsztatów poetyckich. Jakkolwiek tych ostatnich nie trzeba tu usuwać z pola widzenia, kurs dotyczy szkolnego nauczania odbioru (analizy, interpretacji, wartościowania...) i rozmaitego wykorzystania tekstów poetyckich.
} 
wspomniany w niniejszym akapicie jest w procesie kształcenia przyszłego nauczyciela uważany za fundamentalny i doceniany zdecydowanie bardziej niż w polskich uczelniach przygotowujących kadrę dydaktyczną.

Podobnie jak to ma miejsce w polskich realiach, studenci uczestniczą $\mathrm{w}$ zajęciach seminarium magisterskiego (Master's seminar) z dziedziny Teaching of English. Równolegle magistranci muszą realizować kurs określany jako Supervised teaching of English, który polega na analizowaniu doświadczeń zdobywanych $\mathrm{w}$ trakcie praktyk pedagogicznych (o czym poniżej) i wykorzystywaniu ich do formułowania szerszych konkluzji na temat nauczania. Kurs ten jest w istocie bliźniaczy wobec zajęć przedmiotu „Dydaktyka literatury i języka polskiego” realizowanego w polskich uczelniach. Kurs Master's seminar kończy się przygotowaniem i prezentacją pracy magisterskiej (master's project).

Praktyki studenckie trwają przez dwa semestry (cały kurs jest trzysemestralny). Studenci odwiedzają najpierw middle school (czyli pierwsze ogniwo szkoły ponadpodstawowej, gdzie uczy się młodzież w wieku od 11 do 14 lat), później zaś high school, gromadzącą młodzież do lat osiemnastu. Aktywność studentów w pierwszym i drugim semestrze jest zróżnicowana. W pierwszej fazie praktykanci (najczęściej lokowani w szkołach nowojorskich parami) towarzyszą opiekującemu się nimi nauczycielowi w rozmaitych aktywnościach lekcyjnych i pozalekcyjnych. Obserwują pracę anglisty i klasy, towarzyszą uczniom w ich pracy indywidualnej i grupowej (w charakterze nauczycieli pomocniczych), rozmawiają z uczniami, poddają refleksji swoje obserwacje i doświadczenia, w końcu przygotowują i prowadzą fragmenty lekcji.

W fazie drugiej praktykanci są już w pełnym wymiarze włączeni w nauczanie młodzieży, biorą na siebie odpowiedzialność za planowanie procesu nauczania, ocenianie aktywności uczniów, a także włączają się w całokształt pracy szkoły

Wymagania stanu Nowy Jork wobec nauczycieli przedmiotu Language Arts (zwanego także English Language Arts, ELA) stanowią, iż przyszli nauczyciele w dziedzinie kierunkowej (określanej jako English) muszą „uzbierać” 30 punktów (credits). Ponieważ zasadniczy korpus programu Master of Arts jest w całości punktowany nieco niżej, studenci są zobowiązani zaliczyć jeszcze kilka kursów spośród bogatej oferty Teachers College dla anglistów (około 40 propozycji).

Pytanie o różnice programowe w przygotowaniu nauczycieli języka ojczystego w Polsce i w stanie Nowy Jork nie jest dobrze sformułowane. Jakkolwiek macierzyste dziedziny szkolnych polonistów i anglistów uczących w Nowym Jorku są paralelne, to różnice pomiędzy kontekstami, w jakich funkcjonują jedni i drudzy, są odmienne. Kształcenie nauczycieli w Teachers College mocno zakorzenione jest w pragmatystycznej tradycji szkoły Deweyowskiej (sam John Dewey, patron TC, wykładał tam psychologię przez 26 lat). Jest to wciąż tradycja żywa i niepodzielnie dominująca, 
nie tylko w sferze współczesnej filozofii edukacji w USA, ale także w szkolnej praktyce. W Polsce, jakkolwiek dziedzictwo Deweya jest dobrze znane, nigdy nie stało się niczym więcej, jak tylko jednym ze strumieni szkolnego dyskursu. Po drugie - uczelnie i szkoły nowojorskie działają w radykalnie odmiennych warunkach społecznych. Nowy Jork to wciąż i nieodwołalnie „Wielki Tygiel” (mam świadomość podejrzanej świeżości tej metafory), gdzie mieszają się wpływy dziesiątków kultur i tożsamości, wśród których dominują: azjatycka, latynoamerykańska i afroamerykańska. W wielu szkołach na Manhattanie, Brooklynie czy Bronksie pierwszym językiem dominującej większości nie jest angielski. English Language Arts staje się w tych warunkach przedmiotem na kształt języka obcego (drugiego). Jeśliby jednak - mimo wspomnianej odmienności kontekstów nowojorskiego i polskiego - pokusić się o wskazanie głównych różnic programowych pomiędzy zawartością studiów nauczycielskich tam i tu, to należałoby wymienić:

- brak w programach Teachers College przedmiotów o charakterze historii literatury (fundamentalnych $\mathrm{w}$ obszarze polonistyki nauczycielskiej);

- nieobecność w programach TC kursów w rodzaju gramatyki opisowej i historycznej (kluczowych w kształceniu nauczycieli polonistów);

- fundamentalną rolę kursów z dziedziny designing curriculum (układanie własnego/autorskiego programu) w nauczaniu TC (przedmiot nieobecny w polskiej tradycji kształcenia nauczycieli);

- bogactwo oferty programowej TC w sferach: filozofii i psychologii edukacji; prowadzenia badań naukowych; pisania rozpraw naukowych (przy znikomym udziale tych obszarów tematycznych w polskich programach przygotowania nauczycieli).

Powyższa lista jest, oczywiście, niepełna i sporządzona dość pobieżnie. Nawet jednak w tym, niepełnym i z grubsza tylko dokonanym zestawieniu, rzucają się w oczy dwie fundamentalne różnice pomiędzy wizjami przedmiotu "język ojczysty” w USA (bo nie tylko w NY) i w Polsce:

1. Kluczową dyspozycją nauczyciela powinna być umiejętność tworzenia własnego programu (programu dla swojej klasy).

2. Przedmiot ,język ojczysty" nie jest dyscypliną o charakterze tożsamościowym (w rozumieniu tożsamości narodowej czy etnicznej).

Te dwie okoliczności stanowią źródło wielu dalszych, szczegółowych różnic pomiędzy sposobami przygotowania nauczycieli i promowanymi oraz stosowanymi strategiami, metodami, technikami nauczania/uczenia się. Pełniejsza charakterystyka tego zróżnicowania wymagałaby obszernych badań i objętości sporej rozprawy. W nieodległej przyszłości mam nadzieję nieco szerzej zagospodarować to pole. 


\section{Z perspektywy sali wykładowej}

(czy ćwiczeniowej) uczelniana rzeczywistość w TC nie wygląda zasadniczo odmiennie od znanej nam z polskich szkół wyższych kształcących nauczycieli. Zajęcia, które w trakcie krótkiego, intensywnego pobytu dane mi było obserwować, toczyły się głównie w rytm swobodnej, nieśpiesznej rozmowy. Osobowość, temperament i zaangażowanie prowadzącego w kilku przypadkach wiodły do bardziej emocjonalnej dyskusji. Dominującą formą zajęć jest w TC praca w grupach, do czego zresztą skłania stała aranżacja większości sal ćwiczeniowych. W żadnej z tych, które odwiedziłem, stoliki nie były ustawione w znanej nam konfiguracji „klasopodobnej” (rzędy zwieńczone stołem prowadzącego). Drugi najpopularniejszy - obok „grupowego" - model usytuowania stolików to litera U. Aranżacja sal zajęciowych odzwierciedla powszechną w amerykańskiej kulturze edukacyjnej filozofię uczestnictwa - dobrze, aby każdy choć raz się odezwał, do czego jednak nie może czuć się zmuszany. W trakcie rozmów i dyskusji, w których brałem udział na prawach uczestnika zajęć (mój status gościa łagodnie modyfikowano w tym kierunku), uderzała mnie za każdym razem postawa szacunku dla indywidualności, odrębności czy „osobności” studenta. Momentami odnosiłem wrażenie, iż respekt dla tej wartości powstrzymuje uczestników od bardziej wnikliwych pytań czy wniosków. Z drugiej strony - atmosfera otwartości wobec każdego pomysłu czy stanowiska (z szerokiego obszaru zdrowego rozsądku) stanowi czynnik wyraźnie ośmielający, zachęcający do uczestnictwa w rozmowie. Na zajęciach w TC nie ma z tym żadnego problemu.

Technologia cyfrowa jest wszechobecna. Każda sala uczelni jest wyposażona w sprzęt multimedialny z dostępem do Internetu. Także i w Polsce nie jest nam obcy ten stopień technologicznego zaawansowania, ale w TC cyberdydaktyka istotnie się udaje. Wszyscy studenci noszą na zajęcia laptopy lub tablety w funkcji notatników. W trakcie zajęć czytają też rozmaite teksty online - od artykułów naukowych, przez dokumenty oświatowe, po blogi o tematyce edukacyjnej. Piszą komentarze (często na początku i na końcu zajęć) i informacje zwrotne, przesyłają swoje teksty prowadzącemu, ale umieszczając je na platformie Google Docs, udostępniają je równocześnie członkom grupy. Trzeba dodać, że sylabusy wszystkich kursów i harmonogramy zajęć ( $\mathrm{z}$ datą, tematem konkretnego spotkania, literaturą i zadaniami dla studentów) są dostępne online przed rozpoczęciem kursu. Warsztaty metodyczne, polegające na omawianiu lekcji prowadzonych przez studentów odbywają się z wykorzystaniem zapisów wideo, odtwarzanych we fragmentach podczas zajęć. Grupy studentów nie uczęszczają bowiem do szkół w celu hospitacji lekcji, praktykanci natomiast rejestrują swoje zajęcia z uczniami. By zakończyć ten ustęp poświęcony wykorzystaniu nowych technologii, dodam, że studenci nieobecni na zajęciach uczestniczą 
w nich poprzez komunikator Skype (dzięki temu nie tylko słyszą, ale i widzą grupę oraz są widziani).

Pora na najważniejszy akapit tego fragmentu relacji - odpowiedź na pytanie: co stanowi specyfikę kształcenia nauczycieli języka ojczystego w TC? Jaka filozofia przyświeca nauczaniu przyszłych specjalistów od Language Arts? Odpowiedź powinna przerodzić się w osobny artykuł albo i większą publikację. Ponieważ jednak niniejszy tekst jest relacją z podróży i - jak mniemam - doczeka się z mojej strony znaczących uzupełnień (czynionych już na podstawie literatury i kolejnych doświadczeń), pozwolę sobie na zwięzłość i pomijającą pewne niuanse wyrazistość. Filozofia kształcenia w TC (i szerzej: w ambitnym, poszukującym nurcie amerykańskiego dyskursu edukacyjnego) wyrasta z przywiązania do kategorii evidence based learning (uczenie się zaświadczone przez widoczne dowody - jakkolwiek koślawo to brzmi po polsku). Wiemy, co to znaczy: dobrze uczyć - wielokrotnie przekonywał naszą polską grupę Tom Corcoran, socjolog, były przewodniczący Konsorcjum na Rzecz Badań w Edukacji (CPRE) stworzonego przez siedem szacownych amerykańskich uniwersytetów (University of Pennsylvania; Teachers College, Columbia University; Harvard University; Stanford University; University of Michigan; University of WisconsinMadison; Northwestern University). Wiedza ta płynie z badań - długoletnich obserwacji, monitorowania postępów uczniów i działań nauczycieli, z badań o charakterze analiz, z eksperymentów edukacyjnych. Nie miejsce tu na rozszyfrowywanie owej tajemnej „wiedzy”, dość powiedzieć, iż w TC i w kilku innych ośrodkach akademickich w USA hołduje się przekonaniu, że badacze edukacji zidentyfikowali szereg strategii i metod pracy z młodymi ludźmi, a także zdefiniowali wystarczająco dokładnie rolę nauczyciela i pozycję ucznia, by móc twierdzić, iż „wiedzą, co to znaczy - dobrze uczyć”. Wizerunek nauczyciela lansowany przez CPRE ma wiele wspólnego z formułą tego zawodu upowszechnianą od lat przez Johna Hattiego, nowozelandzkiego badacza, profesora Uniwersytetu w Melbourne i dyrektora Melbourne Education Research Institute ${ }^{5}$. Formuła ta, najkrócej rzecz ujmując, przyznaje nauczycielowi daleko idącą swobodę $\mathrm{w}$ kreowaniu kształtu procesu nauczania/uczenia się, zobowiązując go jednocześnie do - kluczowego w tej koncepcji - wytrwałego stawiania uczniowi wyzwań, które mają stymulować młodego człowieka w osiąganiu coraz wyższych poziomów kompetencji. Doskonały nauczyciel to ten, kto stwarza uczniom warunki, by stawali się własnymi nauczycielami - tak w dużym skrócie można by przedstawić motto tego strumienia edukacyjnego dyskursu, który na własny użytek określam jako neoempirym i neopragmatyzm w edukacji. Warunki, o których mowa, nie rodzą się w ogniu radosnej twórczości nawiedzonego pedagoga - one są dość precyzyjnie opisane - między

${ }^{5}$ Książka Hattiego Visible Learning for Teachers: Maximizing Impact on Learning (Routledge, 2012) ukazała się w 2013 roku po polsku jako Widoczne uczenie się dla nauczycieli. Jak maksymalizować siłę oddziaływania na uczenie się, nakładem oficyny Wydawnictwo Szkoły Uczącej Się. 
innymi w jednej z edukacyjnych „biblii” TC, w rozprawie Understanding by Design (Rozumienie przez projektowanie) autorstwa Granta Wigginsa i Jaya McTighe ${ }^{6}$. Autorzy tego wielokrotnie wznawianego w USA opracowania dowodzą, iż fundamentem i warunkiem efektywnego kształcenia jest właściwe planowanie - zarówno lekcji, jak przede wszystkim obszerniejszych faz procesu dydaktycznego, np. działów (obszarów) treści. W owym planowaniu zaś kluczowe miejsce przypada nie rozplanowaniu konkretnych treści kształcenia czy metodom nauczania, lecz sekwencjom działań i aktywności prowadzących do uzyskania dowodów (evidence) na to, iż uczenie się (poznawanie, rozumienie) istotnie „zdarzyło się” w trakcie lekcji czy podczas ich cyklu. Kryteria, cele i sposoby planowania, w dłuższej i krótszej perspektywie, są sednem programu kształcenia nauczycieli w TC i w anglosaskim nurcie nowego empiryzmu edukacyjnego.

\section{Z perspektywy sali lekcyjnej}

nowojorska edukacja może wzbudzić zazdrość polskiego nauczyciela i kogoś, kto - jak piszący te słowa - zajmuje się przygotowaniem polonistów do pracy w szkole. Zazdrość bierze się nie tyle ze świadomości tak znaczącej różnicy w tradycji i sposobach aranżacji szkolnej przestrzeni, z wrażeń dotyczących różnorodności i liczby pomieszczeń dla uczniów w szkołach nowojorskich i nawet nie z poczucia (jednak) pewnego zapóźnienia technologicznego polskich szkół. Ta zazdrość rodzi się również z zestawienia dwóch modeli pracy nauczycieli. Model nowojorski nakłada wprawdzie na uczącego obowiązki o wyższym wymiarze pracy (nauczyciele z reguły nie opuszczają szkoły przed 16.00), ale wyposaża go w narzędzia i możliwości, o których w Polsce możemy jedynie pomarzyć - ze świadomością, że te marzenia nigdy nie staną się rzeczywistością. Ilustracją niech będzie kilka wybranych obrazków z wyprawy, które ułożę w rytm praesens historicum, co wyraziściej ujawni emocje zachłannego obserwatora nowojorskiej szkolnej rzeczywistości.

Lekcja ELA w początkowej klasie high school. Tematem są motywacje działania bohaterów omawianej powieści młodzieżowej. Zaskakuje nas obecność czworga nauczycieli w dwudziestoparoosobowej klasie. Okazuje się, że oprócz nauczyciela prowadzącego jest jeszcze wspomagający i dwie praktykantki (tutaj zwane rezydentkami). Nauczyciel rozdaje rozbudowane materiały w rodzaju naszych kart pracy - fragmenty powieści opatrzone zadaniami, całość podzielona jest na segmenty tematyczne. Po wstępnej rozmowie z całą klasą uczniowie pochylają się nad kartami. Praca idzie nieśpiesznie, mniej więcej połowa klasy w różnym stopniu ociąga się, nieruchomo zawisa nad zadaniami. Prowadzący starają się rozpoznać rodzaj trudności, jakie uczniom sprawiają zadania, chodzą między grupami, rozmawiają z tymi, którzy sygnalizują problemy. Po około 30 minutach (gdy do

\footnotetext{
${ }^{6}$ Wiggins G. and McTighe J., Understanding by Design, 2005, Association for Supervision and Curriculum Development, Alexandria.
} 
końca lekcji jest jeszcze drugie tyle) nauczyciel dzieli klasę na dwie grupy i zabiera tę bardziej oporną w pracy do sali obok. Tam wyświetla na tablicy multimedialnej i rozdaje każdemu uczniowi pomocniczy zestaw zadań. Każde $\mathrm{z}$ nich jest najpierw indywidualnie wykonywane, później zbiorowo omawiane. Każdy uczeń jest skłaniany do wypowiedzi. Praca idzie teraz sprawniej, choć entuzjazmu nadal brak. Do końca lekcji nie ma już żadnych fajerwerków metodycznych.

Lekcja Social studies, ta sama grupa wiekowa. Tematyka lekcji (zbliżonej do naszej historii) dotyczy okresu kształtowania się państwowości amerykańskiej i poczucia tożsamości narodowej - lat 70. XVIII wieku. Z młodzieżą pracują dwie nauczycielki. Porządek lekcji wyznacza sekwencja zdarzeń historycznych („herbatka bostońska”, wojna z Anglikami, stosunki z Indianami), które są najpierw anonsowane przez nauczycielkę (krótkie wprowadzenie, prezentacja map), następnie omawiane w grupach (każdemu wydarzeniu towarzyszy pytanie, na które grupa poszukuje odpowiedzi, np.: Co mogli myśleć i czuć pierwotni Amerykanie, którzy doświadczali w swoim kraju walk kolonistów z Anglikami?), po czym dyskutowane na forum całej klasy. Co ciekawe, tekstami pomocniczymi są rozłożone na stołach powieści historyczne. Zajęcia przebiegają bardzo dynamicznie, wewnątrz grup toczą się ożywione dyskusje, na forum klasy dochodzi do wymiany zdań, która przeradza się w gwałtowną debatę. Wszyscy chcą się wypowiadać, emocje rosną, ale porządek lekcji zostaje utrzymany - nauczycielka pełni rolę arbitra i rozładowuje atmosferę umiejętnie dobranym kontekstem - cytatem, ilustracją, informacją. Świetna, dynamiczna lekcja o ogromnym poziomie zaangażowania uczniów.

Lekcja ELA w wyższej klasie high school. Tematem są znowu motywacje działań bohaterów, tym razem chodzi o ważną dla kultury amerykańskiej powieść Michaela Lewisa Moneyball: The Art of Winning an Unfair Game, opowiadającą historię drużyny baseballowej Oakland Athletics i jej menadżera Billy’ego Beana. W klasie spotykamy dwóch nauczycieli, jednego o posturze i aparycji baseballisty. Okazuje się, że jest tzw. asystentem językowym, który dba o rozwój słownictwa uczniów i poprawność oraz elokwencję wypowiedzi. Po wstępnej rozmowie, która jest rekapitulacją fragmentu fabuły, asystent językowy wprowadza pięć nowych sformułowań, których znaczenie ustala wraz z klasą. Następnie główny nauczyciel odtwarza fragmenty ebooka, w których występują omówione słowa, a rozmowa na temat fragmentów pozwala zweryfikować i doprecyzować ustalone uprzednio znaczenia. Nauczyciel i asystent językowy swobodnie rozmawiają z tymi, którzy chcą zabrać głos. Kilkuosobowa grupa niezainteresowanych w ciszy zajmuje się swoimi sprawami lub nawet nadrabia zaległości senne. Dopóki uczeń nie przeszkadza innym, nie ma powodu wkraczać w jego zachowanie - tłumaczą mi później prowadzący lekcję. „Urobek” zajęć nie jest może obszerny ani głęboki, ale konkretny: pięć nowych struktur językowych, uszlachetniających język wypowiedzi, i rozpoznanie motywacji 
kilku zachowań bohaterów (chodziło o uczciwość postępowania kierownika drużyny wobec zawodników i konkurencyjnych zespołów). Rozsądna propozycja integracji treści literackich i językowych.

Znowu high school, klasa początkowa, lekcja na temat strategii retorycznych $\mathrm{w}$ pisaniu tekstów argumentacyjnych. Schematy struktur retorycznych i całych tekstów (z zaznaczoną segmentacją) pokrywają ściany sali lekcyjnej (w USA, podobnie jak w Wielkiej Brytanii, ściany sal „mówią” - są obwieszone przejrzystymi, często bardzo pomysłowymi grafami, schematami, rysunkami, które uczniowie wykonują dla siebie - aby móc w każdej chwili odświeżyć sobie ważną zasadę, przypomnieć instrukcję, itd.). Jest to kolejna lekcja na ten temat, uczniowie piszą tekst argumentacyjny, korzystając z rozdanych przez nauczyciela materiałów: tekstu, do którego mają się odnieść, i włączonych weń wskazówek i porad, dotyczących kwestii do podjęcia i sugestii na temat sposobu, w jaki mogą to zrobić). Niby nic się nie dzieje, rozlokowani w grupach młodzi ludzie piszą w idealnej ciszy, nauczyciel krąży po klasie, przywoływany raz po raz podniesioną ręką. Pytań jest wiele, uczniowie cierpliwie czekają na swoją kolej. Uderza mnie na tej lekcji cisza i pracowitość każdej ze stron - nauczyciela i uczniów. Jak to się dzieje, że - z pozoru - niezbyt atrakcyjne zajęcia ujawniają ważny aspekt wyzwania i zarazem angażują uczniów? W jaki sposób szkoła nowojorska przekonuje młodzież, że pisanie jest ważne? ${ }^{7}$

W trakcie lekcji czytam sugerowane przez władze oświatowe Nowego Jorku tematy prac pisemnych, nad którymi winni pracować uczniowie, przygotowując się do egzaminów wieńczących nauczanie w szkole średniej (high school). Z niejakim zaskoczeniem konstatuję niemal całkowity brak typowych dla polskiej edukacji tematów związanych z interpretacją utworu i obfitość tych, które dotyczą warsztatu pisarskiego (twórczego). Proporcja ta oddaje nachylenie edukacji literacko-kulturowej w USA.

Że pisanie istotnie jest kluczowe w lansowanym przez TC modelu dydaktyki, że przynosi to fantastyczne rezultaty, przekonują liczne zapisy lekcji zamieszczone na portalu Vimeo, gdzie można oglądać współpracujących z TC nauczycieli rozmawiających rzeczowo z dziewięciolatkami na temat strategii retorycznych w argumentacji! Nie umiem tego oglądać bez zdziwienia i nieszlachetnej zazdrości.

Zbliżając się do podsumowania wrażeń z podróży do NY, proponuję zmianę perspektywy, choć nie diametralną. Powróćmy do Teachers College, gdzie trzydziestokilkuletni Gerrit, do niedawna nauczyciel ELA, a teraz edukator nauczycieli, przybliża nam sposoby pracy z klasą i studentami English Education. Udaje mu się zadziwić mnie, ucznia Bortnowskiego, któremu - jak sądziłem - żadne dydaktyczne szaleństwo nie jest obce. Aby wzbudzić zaciekawienie czytelników (także moimi kolejnymi tekstami na ten temat...), wymienię choć kilka nazw sposobów pracy z praktykantami:

${ }^{7}$ Podobne zajęcia oglądałem w jednej z high school w Chester (zachodnia Anglia), gdzie również zadawałem sobie to samo pytanie. 
FREEZE method (czyli: Stój! lub Ręce do góry!); prowadzenie lekcji w częściach; cztery rogi; co-teaching, jigsaw (znane nieco i u nas). Największe jednak wrażenie robi na mnie prezentacja lansowanego przez Teachers College (i kilka innych ośrodków akademickich) modelu kształtowania umiejętności (i chęci, nawyku!) czytania. Jest to model wieloelementowy, sekwencyjny, spójny wewnętrznie, którego pierwszy stopień stanowi rozpoznanie potencjału czytelniczego ucznia, zaś zwieńczenie - przygotowanie do lektury intertekstualnej. Poznając tę kilkunastostopniową, ogarniającą cały cykl kształcenia, strategię, pytam Gerrita, skąd nauczyciele w szkole amerykańskiej mają na to czas. Nie czytają lektur obowiązkowych? Nie, żaden tekst nie ma u nas tego statusu - odpowiada Gerrit. Poza tym trzymamy się zasady: uczymy czytania, nie konkretnej książki.

Nie wymyślę chyba bardziej efektownej puenty...

\section{O Autorze:}

Witold Bobiński, dr hab., pracownik Katedry Polonistycznej Edukacji Nauczycielskiej na Wydziale Polonistyki UJ. Wieloletni nauczyciel języka polskiego, autor kilku serii podręczników języka polskiego i historii dla różnych typów szkół. W 2008 roku ekspert Ministerstwa Edukacji Narodowej w pracach nad podstawą programową, wieloletni współpracownik Instytutu Badań Edukacyjnych. Ostatnio opublikował: Teksty $w$ lustrze ekranu. Okołofilmowa strategia kształcenia literacko-kulturowego. Na grudzień 2016 roku planowane jest wydanie rozprawy Wykształcić widza. Sztuka oglądania $w$ edukacji polonistycznej. 